\title{
Comparison of the two microsporidia that infect honey bees - a review
}

\author{
Mateja SOKLIČ ${ }^{*}$, Aleš GREGORC ${ }^{1,2}$ \\ ${ }^{1}$ Agricultural Institute of Slovenia, Hacquetova ulica 17, 1000 Ljubljana, Slovenia \\ ${ }^{2}$ Mississippi State University, South MS Branch Experiment Station, Poplarville, MS 39470
}

\begin{abstract}
Two microsporidian species, Nosema apis and Nosema ceranae, infect honey bees (Apis mellifera) worldwide. They are obligate intracellular parasites that multiply in the epithelial lining of the bee's midgut and cause nosemosis. N. ceranae infections were primarily found in Apis cerana and raised interest in the last decade with the discovery of their presence in the European honey bee (Apis mellifera). Nosema spp. utilizes hosts' energetic reserves for the purpose of propagation and disrupts the digestive processes of the bee. Nosemosis reduces the lifespan of a single bee and affects the performance of the colony. It also has an economic impact through the reduction in the honey and pollen yield of severely infected colonies or even causes them to collapse. Lack of effective therapy for nosemosis is of special concern and calls for scientific attention. Although N. ceranae and N. apis are similar in many aspects, there are important differences between them such as clinical signs of infection or the ability to resist low temperatures.
\end{abstract}

Key words: honey bee, microsporidia, Nosema ceranae, Nosema apis

\section{INTRODUCTION}

Two microsporidian species have been described to infect European honey bee, Apis mellifera, namely Nosema apis Zander (1909) and Nosema ceranae (Fries et al. 1996). Microsporidia, Nosema spp., were previously considered as protozoans but were reclassified to the Fungi cluster based on new molecular and ultrastructural evidence (Adl et al. 2005). Outside the host they are found in the form of very resistant spores that can remain infective for years (Fries 1993). N. apis is a long-known and well-studied parasite of the honeybee described in 1909 by a German biologist Zander (cited after Fries 1993).

The natural infection with a new honey bee parasite $N$. ceranae was first reported not more than a decade ago almost simultaneously in Europe (Higes et al. 2006) and Asia (Huang et al. 2007). All infections predating 2005 were previously attributed to $N$. apis but the analyses of stored samples have shown the presence of infection with $N$. ceranae in Europe since at least 1998 (Paxton et al. 2007). The later was primarily the parasite of the economically less important Asian honey bee (Apis cerana) (Fries et al. 1996).
Adult workers as well as queens and drones can become infected with $N$. apis or N. ceranae (Furgala 1962a, Bailey 1972, Higes et al. 2009). Newly emerged adults are free of infection (Smart and Sheppard 2012). After the bee ingests the infective spores, they invade the midgut epithelial cells and multiply intracellularly, causing nosemosis. As their numbers grow, they begin to exert pressure on the cell wall that eventually ruptures and releases cellular content together with the infective spores (Fries et al. 1992, Higes et al. 2007). Thin-walled primary spores are autoinfective while secondary spores voided with feces infect other individuals (Fries et al. 1992). Because of the damage caused to the epithelial layer, the production of digestive enzymes and the absorption of food is impaired (Liu 1984, Malone and Gatehouse 1998, Matašin et al. 2012). The energy demands of honeybee organism can no longer be met and the lifespan is shortened (Fries 1993, Higes et al. 2007, Mayack and Naug 2010). At the colony level the foragers are lost outside the hive and this can result in reduced pollen collection and honey yield (Anderson and Giacon 1992, Botias et al. 2013) or even death of the colony (Fries 1988, Higes et al. 2008). The aim of this article is to review research that has been made on

${ }^{*}$ Correspondence to:

E-mail:mateja.soklic@kis.si 
the both microsporidian species known to cause disease in European honey bee, A. mellifera, compare their effects on individual bee and colony level and point out the questions that still have to be answered.

\section{NOSEMA SPP.}

\section{Taxonomy and morphology}

$N$. apis and $N$. ceranae are the only two microsporidian species known to cause nosemosis in European honey bee $(A$. mellifera). Microsporidia in general are obligate intracellular parasites that use the hollow structure named polar tube for host cell invasion. They belong to the Fungi cluster in Opisthokonta rank based on the results of molecular phylogenetic studies and ultrastructural research (Adl et al. 2005). Microsporidia form oval spores with inner chitin and outer proteinaceous wall, the so-called endospore and exospore. They lack mitochondria. The polar tube or filament is anchored in the anterior end of the spore. It rapidly everts from the spore at the appropriate stimulus and penetrates the wall of the host cell. This is followed by the transport of the sporoplasm through the tube into the host cell. Developmental stages in the cytoplasm can be visualized using electron microscope. Inside the spore, the polar tube is coiled (Vavra and Larsson, 1999). The number of polar filament coils in mature spores is species specific with $N$. apis usually having more than 30 and N. ceranae only 20 to 23 coils (Fries 1989 , Fries et al. 1996). Besides being slightly larger, N. apis spores also appear more uniform in shape and size when observed under the light microscope compared to the spores of $N$. ceranae. Spores of $N$. ceranae measure approximately 4.7 by $2.7 \mu \mathrm{m}$ and are on average $1 \mu \mathrm{m}$ shorter than the spores of $N$. apis. When viewed with the scanning electron microscope the surface of the spores is wrinkled, more profoundly in $N$. ceranae (Ptaszynska et al. 2014). Both species are binucleate (Fries et al. 2006).

\section{Geographical distribution}

Since their first discovery in Europe in 2005, natural infections of European honey bees with $N$. ceranae are reported worldwide and became more common than $N$. apis infections (Klee et al. 2007).

Besides the European honey bee, N. ceranae can also infect the Asian honey bee (Apis cerana), the dwarf Asian honey bee (Apis florea), the giant Asian honey bee (Apis dorsata), Apis koschevnikovi and even some bumblebee species of the genus Bombus (Plischuk et al., 2009; Chaimanee et al., 2010; Botias et al., 2012). In contrast, natural infection with $N$. apis is found only in the European honey bee, although experimental infection was also confirmed in A. cerana (Fries, 1993).

\section{Development of infection}

Representatives of Nosema spp. are obligate intracellular parasites that need the host cell for their propagation. Only recently a successful grow of $N$. ceranae and $N$. apis in a cell culture of a lepidopteran cell line has been made (Gisder et al., 2011). This finding could provide the means necessary for further studies of their morphology, life cycle and pathogenicity.

The bees usually get infected when cleaning the excreta of diseased bees (Bailey and Ball 1991) but also through trophalaxis (Smith 2012, Huang and Solter 2013) or even when visiting contaminated flowers (Evison et al. 2012). Some spores were randomly found at the mouthparts of infected bees (Huang and Solter 2013). After the spores are ingested, they pass the crop and enter the ventriculus where they germinate. If they successfully penetrate the cell wall of a midgut epithelial cell with their hollow polar filament, they inject the sporoplasm into the host cell and begin to multiply. The epithelial cells become filled with newly formed spores, causing host cells to break and spores are released into the ventricular lumen (Dussaubat et al. 2012, Higes et al. 2013). In a fully developed infection, there are around 40 million spores of N. apis present in the midgut (Bailey in Ball 1991) and similar numbers of $N$. ceranae spores. Mature spores pass the alimentary canal and the infected bees release the spores in the environment by defecation. Spores remain viable and capable of infecting a new host for at least 6 months at room temperature, but freezing rapidly causes destruction of $N$. ceranae spores (Fries 2010, Sanchez Collado et al. 2014).

There are reports of $N$. ceranae DNA signal obtained using PCR method (Copley and Jabaji, 2012) or even spore findings in organs and tissues other than the ventriculus (Ptaszynska et al. 2012). But the experiment by Huang and Solter (2013) showed that the positive results could be caused by sampling technique and therefor authors proposed an appropriate alternative sampling to avoid cross contamination. Nosema spp. spores were also found in honey (Giersch et al. 2009) and in corbicular pollen collected by foragers (Higes et al. 2008b).

Natural mixed infections of colonies or even single bees with both species of Nosema also occur (Paxton et al. 2007, Gisder et al. 2010). Forsgren and Fries (2010) applied an even mixture of $N$. apis and N. ceranae spores to worker bees and found no competitive advantage of either within the host. Similar results were obtained in the study by Milbrath and collegues (2015).

Nosemosis caused by $N$. apis shows typical seasonality with low levels of infection in the summer, a low peak in the autumn and a winter rise of infection (Bailey in Ball 1991, Gisder et al. 2010) whereas this pattern appears to be absent in N. ceranae infections in the southern (Higes et al. 2010) but not in the northern parts of Europe (Gisder et al. 2010).

\section{DIAGNOSTICS}

Finding combs soiled with feces is an apparent sign that the colony might be suffering from $N$. apis infection. On the other hand there is a lack of apparent symptoms connected to 
N. ceranae infection besides the poor colony fitness. Samples of live workers are collected for microscopic inspection in both cases. The oldest bees returning from foraging collected at the closed entrance of the hive or bees from side combs and honey super when conditions don't favor flight are appropriate for Nosema spores count. Younger bees are often free of infection and do not reflect the actual status of the colony (Doull 1965, Smart and Shepard 2012). At least 60 bees from the colony have to be examined in order to avoid false negative results according to OIE (2008). Most authors consider the proportion of infected bees more informative than the average spore count (Doull 1965; Fries et al. 1984, Higes et al. 2008a). Whole bees, their abdomens or just ventriculi can be squashed depending on the purpose with one $\mathrm{ml}$ of water per bee and suspension checked under a light microscope (Cantwell 1970). Key to the study of Nosema disease of honeybees (A. mellifera) is the correct identification of $N$. apis and $N$. ceranae spores. With the discovery of $N$. ceranae spores in samples of honeybees (A. mellifera) originating from Spain in 2005 (Higes et al. 2006), the use of light microscopy ceased to be a sufficient method for the confirmation of species. Although the spores of N. ceranae are slightly smaller than $N$. apis spores occurring in naturally infected bees (Fries et al. 1996). In order to distinguish both Nosema species, molecular methods have to be used.

At first, the molecular methods for differentiation of Nosema spp. spores were complicated and required a PCR followed by sequencing (e.g. Higes et al. 2006) or the use of restriction analysis of PCR products (e.g. Klee et al. 2007) until a duplex PCR-method was developed (Martin-Hernandez et al. 2007). Single reaction is needed as it simultaneously amplifies 16S ribosomal RNA regions of either of the two microsporidia. More recently a real-time duplex PCR enabled the quantification of $N$. apis or N. ceranae in a single reaction (Bourgeois et al. 2010).

\section{PATHOLOGY}

\section{Individual bee}

All adult representatives of the honeybee colony are susceptible to infection with $N$. apis and N. ceranae (Furgala 1962a, Higes et al. 2009, Traver and Fell 2011). However, most of the research regarding $N$. ceranae was done on worker honeybees. The most neglected in terms of research are the effects of $N$. ceranae infection on the honeybee queen - not because of minor importance but possibly due to the more complicated experimental set-up. The queen is indeed less likely to become infected because of her specific role in the colony. She does not clean the comb or feed on her own but is rather fed royal jelly by the attending workers and since the Nosema-infected workers start their tasks outside the hive at an earlier age, they are less likely to pass spores to the queen (Wang and Moeller 1970, Dussaubat et al. 2013, Goblirsch et al. 2013). It was recently noted that younger queens are more susceptible to Nosema infection possibly due to immaturity of immune response (Chaimanee et al. 2014). This finding is of extreme importance for commercial queen producers and stresses the need for the development of the appropriate technology to ensure good quality and health status of the produced queens. Commonly packed environment of mating nuclei favors the spread of infection (Gregorc et al. 1992). In turn infected queen can represent a source of infection for the re-queened colony (Czekonska 2000).

Although in the short-term N. ceranae infected queens have all main physiological functions such as vitellogenin titer, the total antioxidant capacity and the queen mandibular pheromones significantly increased (Alaux et al. 2011), a shorter life span is expected (Higes et al. 2009). Degeneration of ovaries, decreased life span and supersedure is documented in honey bee queens with N. apis infection (Hassanein 1951, Furgala 1962a, Loskotova et al. 1980).

In worker bees, $N$. ceranae infection causes imunnosuppression and significant decrease of vitelogenin levels. Vitelogenin normally counteracts with juvenile hormone and prevents premature social maturation from nurse bee to forager (Antunez et al. 2009, Goblirsch et al. 2013).

The mechanisms that caused N. ceranae to prevail over $N$. apis are not clear, but it is the species most often determined in infected samples from Mediterranean region (Tlak Gajger et al. 2010, Gregorc 2013). According to some studies infection with $N$. ceranae causes a higher mortality rate than $N$. apis (Martin-Hernandez et al. 2011; Higes et al. 2008) yet others state that the mortality is not significantly higher (Forsgren and Fries, 2010) or is only pronounced in mixed infections (Milbrath et al. 2015). The results of Mayack and Naug (2009) showed that when bees are fed ad libitum, the median survival time in $N$. ceranae infected and in uninfected bees is similar. It is likely that the accessibility to unlimited amounts of food masks the level of mortality in experiments utilizing caged bees. Sugar syrup consumption is indeed higher in nosemainfected bees in comparison to the uninfected ones (MartinHernandez et al. 2011, Mayack and Naug, 2009). The trehalose level in the haemolymph of free-flying $N$. ceranae infected foragers is lower and reduces at a faster rate if compared to uninfected foragers (Mayack and Naug 2010). As trehalose represents the main source of energy for flight, the lack of it can cause impaired flying abilities of forager bees.

Although there are numerous reports on deleterious effects of $N$. apis on the development and structure of the hypopharyngeal glands of worker bees (Wang and Moeller 1969, Wang and Moeller 1971, Liu 1990), research regarding the status of these glands in $N$. ceranae infected workers is scarce. Underdeveloped glands are probable in such individuals compared to healthy ones since they begin their foraging duties at a younger age (Holt et al. 2013). N. ceranae infection diminishes protein content of food glands in infected A. florea workers (Suwannapong et al. 2010). Infection early in a workers life most likely results in premature atrophy of hypopharyngeal glands and compromises royal jelly production.

Interactions with other stressors are poorly understood. Exposure of N. ceranae infected bees to sublethal doses of pesticides fipronil or thiacloprid results in an increased mortality (Vidau et al. 2011) and bees emerged from brood combs with high level of pesticide residues are more prone to Nosema spp. infection (Wu et al. 2012). Certain pathogens such as viruses are found to add to the primary 
nosema infection as is the case with Chronic bee paralysis virus (Toplak et al. 2013). Analyses of North American honeybee colonies displaying symptoms of colony collapse disorder often showed the presence of $N$. ceranae spores and Invertebrate iridescent virus (Bromenshenk et al. 2010).

\section{Colony level}

N. apis infected colonies have reduced pollen collection ability compared to healthy ones (Anderson and Giacon, 1992). Pollen is essential for normal colony development, for developing bees and the production of royal jelly in the hypopharyngeal glands of nurse bees as it is the main dietary source of protein for honeybees (DeGrandi-Hoffman et al., 2010). If more than $50 \%$ of the bees are Nosema infected, the colony is notably affected and may die-off (Pickard and ElShemy 1989, Higes et al. 2008). In an experiment conducted by Fries and colleges (1984), the honey yield was reduced to half when the average $N$. apis infection within a colony reached about 15 million spores per bee and a little less than $50 \%$ of bees were infected. N. ceranae causes a significant increase in the production of ethyl oleate in infected workers, a primer pheromone important in regulation of the division of labor and can disturb the sensitive equilibrium inside a colony (Dussaubat et al. 2010, Dussaubat et al. 2013). Nosema spp. infected foragers are less likely to successfully return to the hive because of their impaired orientation skills (Kralj and Fuchs, 2009) and diminished energy stores needed for flight (Mayack and Naug 2009, Mayack and Naug 2010). Both factors potentially lower the transmission of disease inside the colony.

\section{CONTROL}

The diagnosis and subsequent treatment of disease in food producing animals is necessary to ensure well-being of the animals, minimize the damage to the productivity and prevent the spread of disease. On the other hand honey bee products have to be safe for the consumer and free of residues of veterinary medicines. Antibiotic substance fumagillin was a long time the therapy of choice for the treatment of nosemosis (Furgala 1962b, Williams et al. 2008). Medicines with fumagillin as active substance are not registered in the European Union. It was found that fumagillin has genotoxic effects (Stanimirović et al. 2007) and also one of the latest studies of fumagillin efficiency in the control of $N$. ceranae showed the level of parasite's reproduction increases significantly at concentrations lower than those prescribed (Huang et al. 2013). Therefore new treatment practices need to be developed. Some of the substances that lowered $N$. ceranae spore levels in preliminary testing include surfactin S2 (Porrini et al. 2010), thymol (Maistrello et al. 2008, Costa et al. 2010) and commercially available product Nozevit (Tlak Gajger et al. 2009). Prophylactic apitechnical measures, such as comb replacement, hygienic handling of the colonies and queen replacement, are effective in lowering the level of infection or reduce spread of disease (Fries 1988, Loskotova et al. 1980). The prevention and control of Nosemosis in queen- breeding apiaries can't be emphasized enough (Gregorc et al. 1992). Freezing of infected beekeeping equipment at $-20{ }^{\circ} \mathrm{C}$ can diminish $N$. ceranae infectivity as it causes the spores to quickly loose viability. The method is simple, inexpensive and safe. Tests should be performed to establish appropriate duration of freezing. Genome-sequencing of $N$. ceranae (Cornman et al. 2009) was the basis to develop the novel therapeutic strategies. Gene silencing method (RNAi) can successfully reduce the levels of N. ceranae spores in the midgut of caged bees, but hasn't been yet tested in field conditions (Paldi et al. 2010).

Another important approach to control Nosemosis is selective breeding of honey bee strains. A recent experiment of selected nosema tolerant honey bees from Denmark showed that they manage to maintain a normal level of apoptotic death rate in infected midgut epithelial cells to prevent spores accumulation in the epithelium (Kurze et al. 2015).

All described measures merely mitigate infection not entirely cure it therefore they should be combined when possible to achieve the best results as is the case with Varroa control.

\section{DISCUSSION}

Despite of abundant data on N. apis and large efforts to describe in such detail the newly discovered $N$. ceranae, many questions remain open. There is a bulk of knowledge concerning the effects of infection with Nosema spp. on survival and certain organs in honeybee workers, mostly under laboratory conditions, but much less in actual field conditions and in combination with other negative factors. A lack of knowledge concerning the outcome of $N$. ceranae infection in honeybee queens is obvious with only four articles covering this topic (Higes et al 2009, Alaux et al. 2011, Traver and Fell 2012, Chaimanee et al. 2014). Negative effects on queen survival and egg-laying similar to those found in N. apis infection are plausible. Spread of infection to newly emerged queens in queen-breeding apiaries should be prevented to assure good quality of queens intended for sale. Selective breeding for Nosema resistant bees could also become an important tool in reducing the incidence of Nosema infections in honey bee colonies.

Today we are facing a worldwide decline of the honeybees. The studies that investigated possible causes of colony depopulation could not point out a single factor responsible for it but have rather shown that different detrimental effects work in concert. Less accessible food sources to bees because of intensive monocultural farming, pesticide exposure, new pathogens, overexploitation, the spread of urban areas and climate changes possibly act together with $N$. ceranae infection to cause massive losses of foragers and colony collapse disorder syndrome (Bromenshenk et al. 2010). It is therefore crucial for the beekeeper to minimize all the negative factors possible and should have the ability to do so through availability of controlling agents and advancement in beekeeping technology. The vast negative effects of nosemosis on individual bees and whole colonies call for search of effective therapy without compromising consumer health. Problem solving should be in the focus of further research. 


\section{ACKNOWLEDGEMENTS}

This work was financially supported by Slovenian research agency.

\section{REFERENCES}

1. Adl SM, Simpson AGB, Farmer MA, Andersen RA, Anderson OR, Barta JR et al. The new higher level classification of eukaryotes with emphasis on the taxonomy of protists. J. Eukaryot. Microbiol. 2005; 52: 399-451.

2. Alaux C, Folschweiller M, McDonnell C, Beslay D, Cousin M, Dussaubat C, Brunet JL, Le Conte Y. Pathological effects of the microsporidium Nosema ceranae on honey bee queen physiology (Apis mellifera). J. Invertebr. Pathol. 2011; 106: 380-5.

3. Anderson DL, Giacon H. Reduced pollen collection by honey bee (Hymenoptera: Apidae) colonies infected with Nosema apis and Sacbrood virus. J. Econ. Entomol. 1992; 85: 47-51.

4. Bailey L. Nosema apis in drone honeybees. J. Apicult. Res. 1972; 11:171-174.

5. Bailey L, Ball BV. Microspora and Protozoa. In: Bailey L, Ball BV (eds.), Honey bee pathology. Academic Press Limited, London, UK. 1991:64-77.

6. Botías C, Anderson DL, Meana A, Garrido-Bailón E, Martín-Hernández R, Higes M. Further evidence of an oriental origin for Nosema ceranae (Microsporidia: Nosematidae). J. Invertebr. Pathol. 2012; 110:108-13.

7. Botias C, Martin-Hernandez R, Barrios L, Meana A, Higes M. Nosema spp. infection and its negative effects on honey bees (Apis mellifera iberiensis) at the colony level. Vet. Res., 2013.44, 25. http://www.veterinaryresearch. org/content/44/1/25 (21.8.2013)

8. Bourgeois AL, Rinderer TE, Beaman LD, et al. Genetic detection and quantification of Nosema apis and Nosema ceranae in the honey bee. J. Invertebr. Pathol. 2010; 103: 53-58.

9. Cantwell GE. Standard methods for counting Nosema spores. Amer. Bee J., 1970; 110: 222-3.

10. Chaimanee V, Warrit N, Chantawannakul P. Infections of Nosema ceranae in four different honeybee species. J. Invertebr. Pathol. 2010; 105, 2: 207-210.

11. Chaimanee V, Chantawannakul P, Chen Y, Evans JD, Pettis, JS. Effects of host age on susceptibility to infection and immune gene expression in honey bee queens (Apis mellifera) inoculated with Nosema ceranae. Apidologie, 2014; 45(4), 451-463.

12. Copley TR, Jabaji SH. 2012. Honeybee glands as possible infection reservoirs of Nosema ceranae and Nosema apis in naturally infected forager bees. J. Appl. Microbiol., $112,15-24$.

13. Cornman RS, Chen YP, Schatz MC, et al. Genomic analyses of the Microsporidian Nosema ceranae, an emergent pathogen of honey bees. PLOS pathogens 2009; 5: 45-54.

14. Costa C, Lodesani M, Maistrello L. Effect of thymol and resveratrol administered with candy or syrup on the development of Nosema ceranae and on the longevity of honeybees (Apis mellifera L.) in laboratory conditions. Apidologie 2010; 41, 2: 141-150.

15. Czekonska K. The influence of Nosema apis on young honeybee queens and transmission of the disease from queens to workers. Apidologie 2000; 31, 6: 701-706.

16. De Grandi-Hoffman G, Chen Y, Huang E, Huang MH. The effect of diet on protein concentration, hypopharyngeal gland development and virus load in worker honey bees (Apis mellifera L.). J. Insect Physiol. 2010; 56: 1184-91.

17. Doull KM. The effects of time of day and method of sampling on the determination of nosema disease in beehives. J. Inverteb. Pathol. 1965; 7: 1-4.

18. Dussaubat C, Maisonnasse A, Alaux C, et al. Nosema spp. infection alters pheromone production in honey bees (Apis mellifera). J. Chem. Ecol. 2010; 36: 522-525.

19. Dussaubat C, Brunet JL, Higes M, Colbourne JK, Lopez J, Choi JH et al. Gut pathology and responses to the microsporidium Nosema ceranae in the honey bee Apis mellifera. PloS one, 2012; 7(5), e37017.

20. Dussaubat C, Maisonnasse A, Crauser D, Beslay D, Costagliola G, Soubeyrand S et al. Flight behavior and pheromone changes associated to Nosema ceranae infection of honey bee workers (Apis mellifera) in field conditions. J. invertebr. Pathol., 2013; 113: 42-51.

21. Evison SEF, Roberts KE, Laurenson L, Pietravalle S, Hui J, et al. (2012) Pervasiveness of Parasites in Pollinators. PLoS ONE 7(1): e30641. doi:10.1371/journal.pone.0030641

22. Forsgren E, Fries I. Comparative virulence of Nosema ceranae and Nosema apis in individual European honey bees. Vet. Parasitol. 2010; 170: 212-217.

23. Fries I. Comb replacement and Nosema disease (Nosema apis) in honey bee colonies. Apidologie 1988; 19: 343354.

24. Fries I. Observations on the development and transmission of Nosema apis spores Zander in the ventriculus of the honey bee. J. Apicult. Res. 1989; 28: 107-117.

25. Fries I. Infectivity and multiplication of Nosema apis z. in the ventriculus of the honey bee. Apidologie, 1988; 19: 319-328.

26. Fries I. Nosema apis - a parasite in the honey bee colony. Bee world 1993; 74, 1: 5-19.

27. Fries I. Nosema ceranae in European honey bees (Apis mellifera). J. Invertebr. Pathol. 2010; 103: S73-S79.

28. Fries I, Ekbohm G, Villumstad E. Nosema apis, sampling techniques and honey yield. J. Apicult. Res.1984; 23: 102105.

29. Fries I, Feng F, da Silva A, Slemenda SB, Pieniazek NJ. Nosema ceranae Sp. (Microspora, Nosematidae), morphological and molecular characterization of a microsporidian parasite of the Asian honey bee Apis cerana (Hymenoptera, Apidae). Europ. J. Protistol. 1996; 32: 356-365.

30. Fries I, Granados RR, Morse RA. Intracellular germination of spores of Nosema apis. Apidologie. 1992; 23: 61-70.

31. Fries I, Martin R, Meana A, Garcia-Palencia P, Higes M. Natural infections of Nosema ceranae in European honey bees. J. Apic. Res. 2006; 45: 230-3.

32. Furgala B. The effect of the intensity of Nosema inoculum on queen supersedure in the honey bee, Apis mellifera Linnaeus. J. Insect. Pathol. 1962 a; 4: 429-432. 
33. Furgala B. Residual fumagillin activity in sugar syrup stored by wintering honeybee colonies. J. Apicult. Res. 1962 b; 1: 35-37.

34. Giersch T, Berg T, Galea F et al. Nosema ceranae infects honey bees (Apis mellifera) and contaminates honey in Australia. Apidologie 2009; 40: 117-123.

35. Gisder S, Hedtke K, Moeckel N et al. Five-year cohort study of Nosema spp. in Germany: does climate shape virulence and assertiveness of Nosema ceranae? Appl. Environ. Microbiol. 2010; 76: 3032-3038.

36. Gisder S, Moeckel N, Linde A et al. A cell culture model for Nosema ceranae and Nosema apis allows new insights into the life cycle of these important honey beepathogenic microsporidia. Environ. Microbiol. 2011; 13: 404-413.

37. Gregorc A, Fijan N, Poklukar J. The effect of Apis mellifera carnica Polm. worker bee source for populating mating nuclei on degree of infection by Nosema apis Zander. Apidologie. 1992; 23: 241-244.

38. Gregorc A. Spremljanje kakovosti vzrejenih matic kranjske čebele za programsko obdobje 2011 - 2013. Report. Agricultural Institute of Slovenia, 2013.

39. Hassanein MH. Studies on the effect of infection with Nosema apis on the physiology of the queen honey-bee. J. Cell Sci. 1951; 92: 225-231.

40. Higes M, Martin R, Meana A. Nosema ceranae, a new microsporidian parasite in honeybees in Europe. J. Invertebr. pathol. 2006; 92: 93-95.

41. Higes M, Garcia-Palencia P, Martin-Hernandez R, Meana A. Experimental infection of Apis mellifera honeybees with Nosema ceranae (Microsporidia). J. Invertebr. Pathol. 2007; 94:211-217.

42. Higes M, Martin-Hernandez R, Botias C, Garrido-Bailon E, Gonzalez-Porto AV, Barrios L, del Nozal MJ, Bernal JL, Jimenez JJ Garcia-Palencia P, Meana A. How natural infection by Nosema ceranae causes honeybee colony collapse. Environ. Microbiol. 2008a; 10: 2659-2669.

43. Higes M, Martin-Hernandez R, Garrido-Bailon E, et al. Detection of infective Nosema ceranae (Microsporidia) spores in corbicular pollen of forager honeybees. J. Invertebr. Pathol. 2008b; 97:76-8.

44. Higes $M$, Martin-Hernandez R, Garcia-Palencia P, et al. Horizontal transmission of Nosema ceranae (Microsporidia) from worker honeybees to queens (Apis mellifera). Environ. Microb. Rep. 2009; 1:495-8.

45. Higes M, Martin-Hernandez R, Meana A. Nosema ceranae in Europe: an emergent type $\mathrm{C}$ nosemosis. Apidologie. 2010; 41:375-92.

46. Higes M, Juarranz A, Dias-Almeida J, Lucena S, Botias C, Meana A, Garcia-Palencia P, Martin-Hernandez R. 2013. Apoptosis in the pathogenesis of Nosema ceranae (Microsporidia: Nosematidae) in honey bees (Apis mellifera). Environ. Microbiol. Rep. 5(4), 530-6.

47. Huang WF, Jiang JH, Chen YW, et al. A Nosema ceranae isolate from the honeybee Apis mellifera. Apidologie 2007; 38: 30-7.

48. Huang WF, Solter LF. Comparative development and tissue tropism of Nosema apis and Nosema ceranae. J Invert Pathol 2013; 113, 1: 35-41.

49. Klee J, Besana AM, Genersch E, et al. Widespread dispersal of the microsporidian Nosema ceranae, an emergent pathogen of the western honey bee, Apis mellifera. J. Invertebr. Pathol. 2007; 96, 1: 1-10.

50. Kralj J, Fuchs S. Nosema sp influences flight behavior of infected honey bee (Apis mellifera) foragers. Apidologie, 2010; 41, 1: 21-8.

51. Liu TP. Ultrastructure of the midgut of the worker honey bee Apis mellifera heavily infected with Nosema apis. Journal of invertebrate pathology, 1984; 44: 282-291.

52. Liu TP. Ultrastructural changes in the secretion granules of the hypopharyngeal glands of the honeybee infected by Nosema apis and after treatment with fumagillin. Tissue and Cell 1990; 22, 4: 523-31.

53. Loskotova J, Peroutka M, Vesely V. Nosema disease of honeybee queens (Apis mellifica). Apidologie 1980; 11, 2: 153-61.

54. Maistrello L, Lodesani M, Costa C, Leonardi F, Marani G, Caldon M, Mutinelli F, Granato A. Screening of natural compounds for the control of nosema disease in honeybees (Apis mellifera). Apidologie 2008; 39: 436-45.

55. Malone LA, Gatehouse HS. 1998. Effects of Nosema apis infection on honey bee (Apis mellifera) digestive proteolytic enzyme activity. J. Invertebr. Pathol., 71, 16974 .

56. Martin-Hernandez R, Meana A, Prieto L, Salvador AM, Garrido-Bailón E, Higes M. 2007. Outcome of colonization of Apis mellifera by Nosema ceranae. Appl. Environ. Microbiol., 73, 20: 6331-8.

57. Martin-Hernandez R; Botias C; Barrios Let al. Comparison of the energetic stress associated with experimental Nosema ceranae and Nosema apis infection of honeybees (Apis mellifera). Parasitol. Res. 2011; 109, 3: 605-12.

58. Mayack C, Naug D. Energetic stress in the honeybee Apis mellifera from Nosema ceranae infection, J. Invertebr. Pathol. 2009; 100, 3: 185-8.

59. Mayack C; Naug D. Parasitic infection leads to decline in hemolymph sugar levels in honeybee foragers. J. Insect Physiol. 2010; 56, 11:1572-5.

60. Matašin Ž, Nejedli S, Tlak Gajger I. 2012. Leucine aminopeptidase activity in the midgut of nosema diseased honeybees (Apis mellifera). Veterinarski arhiv, 82 (6), 599-607.

61. Milbrath MO, van Tran T, Huang WF, Solter LF, Tarpy DR, Lawrence F, Huang ZY. Comparative virulence and competition between Nosema apis and Nosema ceranae in honey bees (Apis mellifera). J. Invertebr Pathol. 2015; 125:9-15. doi: 10.1016/j.jip.2014.12.006.

62. Naug D, Gibbs A. Behavioral changes mediated by hunger in honeybees infected with Nosema ceranae. Apidologie 2009; 40, 6: 595-9.

63. Paxton RJ, Klee J, Korpela S, et al. Nosema ceranae has infected Apis mellifera in Europe since at least 1998 and may be more virulent than Nosema apis. Apidologie 2007; 38, 6: 558-65.

64. Pickard RS, Elshemy AAM. Seasonal variation in the infection of honeybee colonies with Nosema apis zander. J. Apicult. Res. 1989; 28, 2: 93-100.

65. Plischuk S, Martin-Hernandez R, Prieto L, Lucía M, Botías C, Meana A, Abrahamovich AH, Lange C, Higes M. South American native bumblebees (Hymenoptera: 
Apidae) infected by Nosema ceranae (Microsporidia), an emerging pathogen of honeybees (Apis mellifera). Environ. Microb. Rep. 2009; 1, 2: 131-135.

66. Porrini MP., Audisio CM., Sabate DC., et al. Effect of bacterial metabolites on microsporidian Nosema ceranae and on its host Apis mellifera. Parasitol. Res. 2010; 107, 2: 381-8.

67. Ptaszynska AA, Borsuk G, Anusiewicz M, Mulenko W. Location of Nosema spp. spores within the body of the honey bee. Med. Weter. 2012; 68, 10: 618-21.

68. Ptaszyńska A, Borsuk G, Mułenko W, Demetraki-Paleolog J. Differentiation of Nosema apis and Nosema ceranae spores under Scanning Electron Microscopy (SEM), J. Apicult. Res. 2014; 53: 537-544.

69. Sánchez Collado JG, Higes M, Barrio L, Martín-Hernández R. Flow cytometry analysis of Nosema species to assess spore viability and longevity. Parasitol. Res. 2014; 113, 5: 1695-1701.

70. Smith ML. The honey bee parasite Nosema ceranae: transmissible via food exchange? PLoS ONE 2012; 7(8): e43319. doi:10.1371/journal.pone.0043319

71. Stanimirović Z, Stevanović J, Bajić V, Radović I. Evaluation of genotoxic effects of fumagillin by cytogenetic tests in vivo. Mutation Res. 2007; 628: 1-10.

72. Suwannapong G, Maksong S, Seanbualuang P, Benbow ME. Experimental infection of red dwarf honeybee, Apis florea, with Nosema ceranae. Journal of Asia-Pacific Entomology, 2010; 13: 361-364.

73. Tlak Gajger I, Vugrek O, Pinter Lj, Petrinec Z. "Nozevit patties" treatment of honeybees (Apis mellifera) for the control of Nosema ceranae disease. Am. Bee J. 2009; 149, 1053-1056.

74. Tlak Gajger I, Vugrek O, Grilec D, Petrinec Z. Prevalence and distribution of Nosema ceranae in Croatian honeybee colonies. Veterinarni Medicina, 2010. 55, 9: 457-462.

75. Traver BE, Fell RD. Low natural levels of Nosema ceranae in Apis mellifera queens. J. Invertebr. Pathol, 2012; 110, 3: 408-410.

76. Vavra J, Larsson JIR. Structure of the microsporidia. 7 84. In: Wittner M, Weiss LM. 1999. The Microsporidia and microsporidiosis. Washington DC: ASM. 553 p.

77. Vidau C; Diogon M; Aufauvre J et al. Exposure to sublethal doses of fipronil and thiacloprid highly increases mortality of honeybees previously infected by Nosema ceranae. PLoS ONE 2011; 6, 6: 56-64.

78. Wang DI, Moeller FE. Histological comparisons of the development of hypopharyngeal glands in healthy and nosema-infected worker honey bees. J. Invertebr. Pathol. 1969; 14: 135-42.

79. Wang DI, Moeller FE. The division of labor and queen attendance behavior of nosema-infected worker honey bees. J. Econ. Ent. 1970; 63: 1539-41.

80. Wang DI, Moeller FE. Ultrastructural changes in hypopharyngeal glands of worker honey bees infected by Nosema apis. J. Invertebr. Pathol. 1971; 17, 3: 308-12.

81. Williams GR, Sampson MA, Shutler D, Rogers REL. Does fumagillin control the recently detected invasive parasite Nosema ceranae in western honey bees (Apis mellifera)? J. Invertebr. Pathol. 2008; 99, 342-4.

82. Wu JY, Smart MD, Anelli CM, Sheppard WS. Honey bees
(Apis mellifera) reared in brood combs containing high levels of pesticide residues exhibit increased susceptibility to Nosema (Microsporidia) infection. J. Invertebra. Pathol. 2012; 109, 326-9. 


\section{Primerjava mikrosporidijev, ki povzročata okužbe pri medonosni čebeli - pregledni članek}

\section{IZVLEČEK}

Nosema apis in Nosema ceranae sta vrsti mikrosporidijev, ki povzročata okužbe pri medonosni čebeli (Apis mellifera) širom sveta. Gre za obligatne znotrajcelične parazite, ki se razmnožujejo v črevesnem epitelu čebele in povzročajo nosemavost. Okužbe z N. ceranae so prvič odkrili pri Apis cerana, zanimanje zanje pa je naraslo v zadnjem desetletju, ko so ugotovili njihovo prisotnost pri medonosni čebeli (A. mellifera). Oba parazita iz rodu Nosema porabljata energetske zaloge gostitelja za lastno razmnoževanje in škodujeta njegovim prebavnim procesom. Okužba skrajšuje življenjsko dobo čebel in prizadene delovanje celotne čebelje družine. Nosemavost ima negativen učinek na donos medu in cvetnega prahu pri močno okuženih družinah, lahko pa celo privede do njihovega propada. Pomanjkanje učinkovitih metod zdravljenja nosemavosti zahteva razvoj novih. Kljub številnim podobnostim obstajajo med obema povzročiteljema pomembne razlike kot so klinični znaki okužbe in odpornost na nizke temperature.

Ključne besede: medonosna čebela, mikrosporidiji, Nosema ceranae, Nosema apis 